\title{
Task-based teaching of college English combined with network multimedia technology
}

\author{
Huimin Zhao ${ }^{1, \text { a }}$ \\ ${ }^{1}$ Bohai university, Jinzhou, 121013 China \\ ahmzhao2008@163.com
}

Keywords: Network Multimedia; Task-based teaching; College English Teaching.

\begin{abstract}
The subjectivity of students is neglected in traditional English teaching mode, and Teaching is not connected with learning. The learning enthusiasm as well as learning efficiency of students is low. Based on network and multimedia, the task-based teaching mode can change this situation. In this article, the author puts forward the suggestions of college English teaching based on task-based approach.
\end{abstract}

\section{Introduction}

With the rapid development of science and technology, advanced computer network technology (CNT) and multimedia technology have been applied to educational field. At present, the multimedia network teaching system has been formed and become a new trend in teaching. However, in the process of multimedia network teaching, some teachers rely heavily on teaching-aid means when they conduct multimedia network-aided teaching. The teachers ignore the emotional factors of students and communicate less with them. Therefore, the teaching idea is difficult to present and teaching methods are rarely applied. These problems attract the public's concern about modern multimedia language teaching. The newly issued College English Curriculum Standards clearly states that the overall objective of English courses in undergraduate phase is to cultivate students' comprehensive abilities of using languages. In addition, all levels of teaching objectives are described as requiring students "being able to do something", underlining that "teachers should not simply impart the language knowledge but try to use task-based teaching approach". In this way, students with a definite task objective develop their language, ideas, communication, and cooperation abilities during their daily life, and therefore improve their comprehensive abilities of using languages. In this study, combining with a specific college English teaching case, the author conducts college English teaching practice based on the task-based teaching method by using multimedia network as teaching-aid means.

\section{Task-based teaching method}

The theoretical basis of task-based teaching method is constructivism theory. Based on psychology, philosophy and anthropology, constructivism is the forefront theory of cognitive psychology and has profoundly influenced the teaching reform of current world. From the interaction between internal and external causes, constructivism emphasizes subjective initiatives of a cognitive subject in the process of meaning understanding and construction, and opens a new horizon and filed for English teaching reform. Constructivism provides a revelation for foreign language teaching that the teaching is not to learn language knowledge simply but regard foreign languages as a mean of cultivating students' abilities.[1] Learners should combine the learning and utilization of foreign knowledge with the cultivation of personal ability. The basic characteristic of task-based teaching is that teaching is planned and organized with the "task" as a core unit. Tasks in task-based teaching are not ordinary curricular or extracurricular teaching and learning activities isolated or combined at random but an organic component of the overall system (course). The forms of tasks are to use a language to deal with the problems in simulated or real life. All aspects of the tasks are effectively combined and interacted to realize the overall goal of the courses. Task-based teaching method is one 
of learning-centered teaching methods. This kind of teaching methods mainly focuses on cognitive process and psycholinguistics process of the second language teaching. In addition, the teaching method is trying to provide opportunities for learners to take part in open-type communicative tasks by involving meaning-focused activities in classes. In classroom, the teaching method is operated by conducting a series of teaching tasks. In the process of performing tasks, learners focus on the meaning of language communication. Moreover, they make full use of the obtained targeted language resources to acquire the desired information by communicating with others, so that they can finish tasks. The learning process is to reach the expected teaching objective by using open methods.[2]

\section{Task-based teaching strategies of college English}

Students vary significantly in various aspects such as learning ability and personality. Therefore, task-based teaching requires teachers to rationally organize students with different grades, personalities, cultural backgrounds and genders in a group, so that every student can find a suitable role in the group. Therefore, the tasks set by teachers have to be enlightening, hierarchical and diverse, and are finished from different aspects by using different methods, creating opportunities for every student's personality development. In addition, teachers should not set a unified standard but allow the existence and development of disparities. While assigning same materials to students, teachers can set different requests and offer help of different degrees to students. Or, teachers can send different materials to different students while require them to finish the same tasks.

To clearly explain the application of task-based teaching method to college English classroom teaching by using multimedia network, the study makes a specific explanation taking the intensive reading teaching of college English as an example. The following section analyzes the application process of the teaching approach using multimedia networks in intensive reading teaching of college English from various aspects, including teaching content, teaching mode and teacher and student roles. This study takes unit 10 in Book Five of intensive reading course as an example, which is a speech draft written with relatively simple sentences easily to be understood. Students are taught with the idea to acquire beneficial information by applying task-based teaching method, so that they can acquire knowledge on multi-media network platforms. The author designs specific tasks at three stages, including before, in and after classes. Students finish tasks under the guidance of teachers. In addition, their comprehensive abilities of using languages and comprehensive qualities are improved through perception, experience, practice and operation. [3]

\section{Pre-tasks: Introducing scenes and arousing associations}

The proposed teaching approach suggests using networks and media to design scenes and present teaching tasks of courses as so to inspire students' associative thought. By doing so, students can arouse associations based on their existing knowledge structure to combine old and new knowledge learned at present and assign certain meaning to the new knowledge. Tasks at the stage is to require students to collect materials about the poor life of black slaves and the life-time, sound images and textual materials of Martin Luther King Jr. In addition, students make a multimedia brief biography of the civil rights leader under the guidance of teachers. In this way, students' abilities of reading, collecting, and processing information get exercises. This teaching is mainly conducted in the form of group work. Students can consult related books in libraries and reading rooms as well as surf the internet for the textual and audio-visual materials. The whole class divides into several groups, each which contains 4 to 5 students and teachers require all groups to collect related materials and make a brief biography of Martin Luther King under the guidance of teachers. Every group need to report their achievements to the whole class in class a week later. Before the group discussion, each member in a group should know own task and get a task card. The group members separately take actions and look up related information by surfing the internet or going to the libraries and reading rooms. In addition, they primarily exchange the acquired information with other group members and then the group discusses and further processes the materials acquired by all members. Then the group invites a teacher to assist the production of the multi-media biography together after systematizing the materials. Finally, each group selects a representative to report their achievements in class. The 
implementation result proves that their achievements are greatly out of teachers' expectations. The materials include films describing the history background as well as country music that reflects American Civil War. In addition, it contains pictures of the poor life of black slaves as well as live video and audio of Martin Luther King. In the activity, teachers mainly encourage students to use English to express various ideas and experiences.

Classroom tasks: students searching and independently investigating resources, while teachers provide timely inspiration and individual instruction

Students have entered to a learning environment where they can study freely by looking up internet resources. Students fulfill the learning tasks and reach their own learning objectives by utilizing various information resources. Then teachers give directions in terms of learning focuses and difficult points according to the learning task achievements reported by students, to further consolidate students' knowledge. Moreover, by using rich resources obtained from the internet, students can improve their abilities of using languages to achieve the real purpose of learning languages while working on the tasks. The specific contents and operating process at this stage are as follow: First is to assign tasks. Each group presents and explains its own brief biography of Martin Luther King to the whole class. The second step is to set goals, changing teacher-oriented lecturing classes to classes of interaction among students and teacher-student interaction, so as to enhance students' listening and speaking abilities. The activities in class are generally conducted in groups to conduct cooperative learning. Students can ask questions to other group members while they present the achievement. Similarly, they can answer questions from other group members and teachers to achieve the purpose of interaction among students and teacher-student interaction. In addition, each group needs to analyze the achievements of other groups and teachers fairly evaluate the achievements of all groups. In this way, each group can learn from others' strong points to offset its own weakness. Mutual evaluation among groups and teachers' evaluation break traditional pattern of passive impartation and acceptation of knowledge and carry out democratic open-type teaching. Under the open-type teaching, students are allowed to make mistakes and have divergences and they also can come out with most fantastic ideas and freely speak to active the classroom atmosphere. In this way, teaching and learning in classes are more creative. [4]

\section{Post-tasks: resources sharing, mutual communication and cooperative learning}

After independently exploring knowledge and finishing learning tasks, students can conduct group discussion and negotiation to communicate with each other by employing networks. Then, by presenting their own learning achievements, students can share their group thinking and wisdom. In addition, by communicating with each other on the internet, students can learn from others' advantages and deepen their understanding and consolidation of learned knowledge. In this way, students can promote mutually and improve together in internet learning. The specific contents and operating process at this stage are as follow: The primary task in this phase is to look up materials mutually among groups. The discussed topic among groups is what can we learn from Martin Luther King and then comment him to train students' writing abilities. The activity pattern is group cooperation at first and then individual operation. The members of each group operate individually and choose a topic to come out a written report. After a series of activities such as collecting, analyzing and selecting materials and group cooperation and discussion, students find writing is not as difficult as they thought and understand the meanings of autonomous learning and cooperative learning.

\section{Conclusions}

Task is an important concept not only in task-based teaching method but also in the whole language teaching even classroom teaching theory of non-language subjects. Teachers' selection on tasks in a large extent determines the teaching objectives, the learning pattern, the functions of teachers and students in learning process and even expression and evaluation patterns for learning achievements. Task-based teaching is a people-oriented effective teaching method which reflects language values and contains advanced teaching principles and concepts. The research suggests 
English educators to combine advanced network multimedia technology with task-based teaching method to promote English teaching by utilizing advanced technologies and teaching concepts.

\section{Acknowledgements}

This work is supported by Social Science Foundation of Liaoning Province (No. L15DWW005) and Bohai University Teaching Reform Project (No.BDJG15QNB002).

\section{References}

[1] W. Littlewood, Principles and Practice of Task-Based LanguageTeaching[J]. Foreign Language Teaching in Schools, 2004.

[2] N. Prabhu, Second Language Pedagogy: A Perspective[M]. Oxford: Oxford University Press, 1987.

[3] P. Skehan, A Cognitive Approach to Language Learning[M]. Shanghai: Shanghai Foreign Language Press, 1998.

[4] J. Willis, D. Willis, Challange and Change in Language Teaching[M].Shanghai: Shanghai Foreign Language Education Press, 2002. 